\title{
骨破壊を伴った上顎洞血瘤腫症例
}

\author{
川井田政弘・甲能 直幸 \\ 川崎 順久・福田 宏之*
}

\section{Blood Boil of the Maxillary Sinus with Massive Bone Destruction; A Case Report}

\author{
Masahiro Kawaida, Naoyuki Kohno and Yoshihisa Kawasaki \\ (Tokyo Metropolitan Ohtsuka Hospital) \\ Hiroyuki Fukuda \\ (Keio University School of Medicine)
}

\begin{abstract}
A 59-year-old man complained of swelling of the cheek, nasal obstruction and nasal bleeding. Radiographic examination showed massive bone destruction of the left maxillary sinus. The tentative diagnosis was malignant tumor of the maxillary sinus. The patient was treated with maxillotomy. Histopathological examination revealed no evidence of malignancy, but hematoma and necrotic tissue with pseudostratified columnar ciliated epithelium.

Blood boil is a clinical term and the etiology is indefinite. It is possible for several causative factors to exist. It is difficult to distinguish such a lesion from malignant tumor and careful examination with long term follow-up is necessary.
\end{abstract}

Key words: blood boil, maxillary sinus, bone destruction, maxillary cancer

\section{はじめに}

副鼻腔に生じるいわゆる血瘤腫は比較的稀な 疾患で，上顎洞に好発するが，悪性腫瘍との鑑 別がしばしば困難であることが知られている. 本症は臨床的な診断名であり，本質的には良性 疾患であるが，病理学的に確立されたものでは なく，その本態や成因などは明確ではない.

われわれは骨破壊を伴い, 当初悪性腫瘍が強 く疑われた本症の一例を経験した. 本症例を報 告するとともに，その本態や成因について考察
を行った。

患者 : 59歳, 男性.

主訴 : 左煩部腫脹, 左鼻閉塞, 左鼻出血.

既往歴 : 1957年頃 (27歳時)に肺結核で右肺上 葉切除術を受けた。

家族歴 : 特記すべきことなし.

現病歴 : 1988年 7 月頃より左煩部腫脹が出現 し, 同年 8 月頃に近医歯科を受診し, 霊胞の疑 いといわれたが，特に疼痛もなかったためその 
まま放置していた。1989年 2 月頃より，左鼻閉 塞が出現し，徐々に増強した。すた，同年 3 月 頃より, 頻回に左片側性の鼻出血が生じるよう になったため，1989年 5 月26日に近医耳鼻咽喉 科を受診した．左鼻咠を指摘され，しばらく鼻 処置などの保存的治療を受けていたが，軽快し ないため，手術を勧められ，1989年 7 月 7 日に 紹介されて受診した。

初診時現症：左頓部に軽度の腫脹を認めたが， 圧痛や自発痛の訴えはなく, 外鼻変形は認めな かった，鼻内所見では，左中鼻道から左総鼻道 にかけて表面やや山凸で浮腫状，全体的には灭 白色で部分的に暗赤色の鼻茸様腫瘤を認め，一 部に凝血塊の付着がみられた。な扮, 眼球運動 は正常で, 視力障害はなく, 腫脹した頸部リン パ節は触知しなかった。

初診時一般検査所見: 末梢血検査では, 赤血 球数 $451 \times 10^{4} / \mathrm{mm}^{3}$, 血色素量 $13.6 \mathrm{~g} / \mathrm{d} 1$, マトクリット值 $41.9 \%$, 血小板数 $24.7 \times 10^{4}$ / $\mathrm{mm}^{3}$, 白血球数 $6,900 / \mathrm{mm}^{3}$, 白血球百分率に 異常なし，血液凝固系検査ならびに血清生化学 検查, 一般尿検查, 心電図で特に異常以認めら れなかった。胸部X線写真で右上肺野泫上葉 切除術にともなら変形が認められた。

鼻・副鼻腔X線検查所見：単純撮影では左側 の鼻腔㧊よび上顎洞，篩骨洞に強度の陰影を認 めた．特に後頭頃位撮影法では左鼻腔側壁の骨 陰影が不明瞭であり，左上枵洞の外側壁の骨欠 損が認められた(図 1)。正面断層撮影でも同様 に左側の鼻腔抽よび上顎洞，篩骨洞に濃厚陰影 を認めるとともに，鼻中隔を右側へ圧排してい る所見がみられた(図 2 ).

鼻・副鼻腔 CTscan 検查所見 : 左上顎洞加ら 左鼻腔に膨張性・進展性に存在する mass を認 め, 鼻中隔を右方へ圧排し, 一部左側の側頭下 窩にも及んでいた。また，左上顎洞の前壁下部 ならびに内側壁，外側壁，翼突起を除く後壁の 骨欠損が認められた(図 3 )。左側の前部および

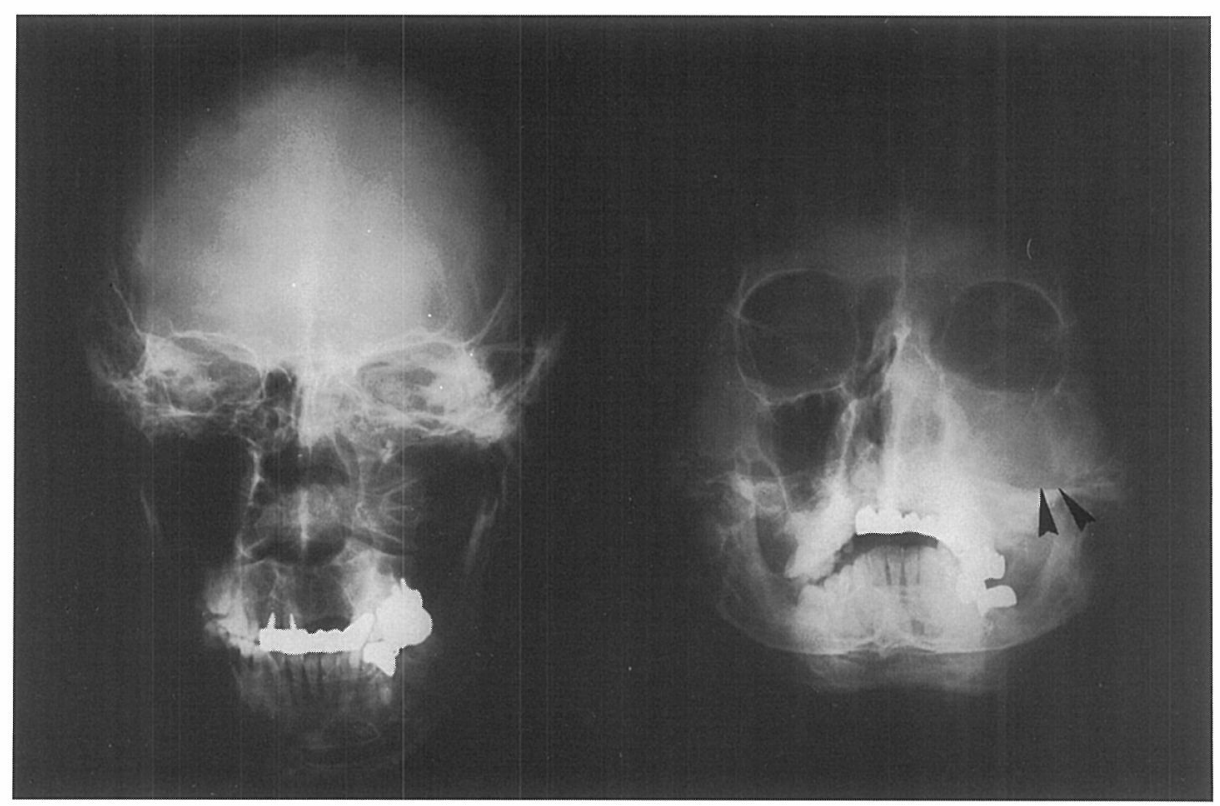

図 1 鼻·副鼻腔X線検査所見 (単純撮影)

後頭前頭位撮影法(左)ならびに後頭皕位撮影法(右). 左側の上顎洞と篩骨洞に陰影を認める とともに，左上顎洞外側壁の骨欠損がみられる( 
後部篩骨洞にも mass の存在を思わせる所見が みられたが，骨壁の圧排や欠損などは認めなか った。

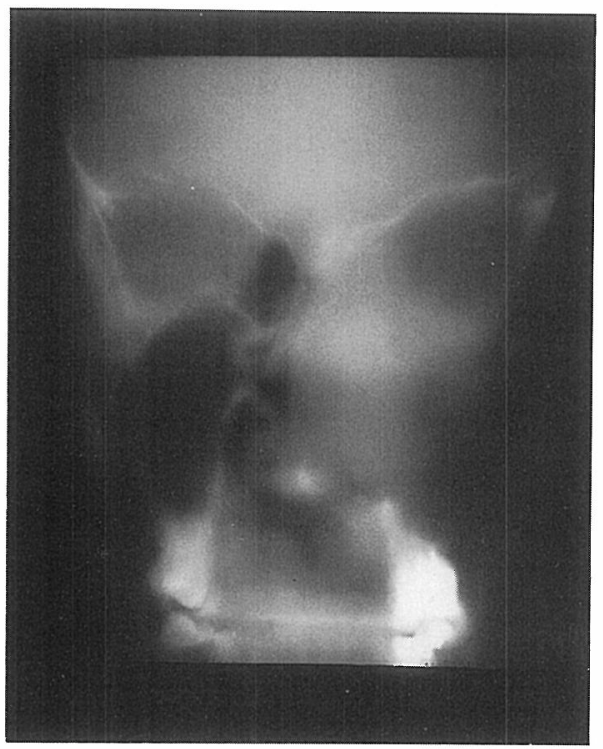

図 2 鼻·副鼻腔X線検査所見 (正面断層撮影)

鼻尖より後方へ $6 \mathrm{~cm}$ のレベルの断層写真. 左側の鼻腔特よび上顎洞，篩骨洞に濃厚陰影 を認め，鼻中隔を右側へ圧排している所見が みられる。
手術時所見：左上顎洞から左鼻腔に及ぶ悪性 腫瘍が疑われたため，1989年 7 月11日に，注射 用 nicardipin $\mathrm{HCl}$ (商品名 Perdipine ${ }^{\circledR}$ 注)の持 続静注による低血圧法(収縮期血圧を約 100 $\mathrm{mmHg}$ に維持)を併用した気管内挿管による吸 入麻酔下に左上顎洞試験開放術を含む左副鼻腔 手術を入院の上施行した．左上縜洞の上壁和よ び下壁は注潼正常であったが，前壁下部拈よび 後壁，外側壁，内側壁の一部に骨欠損を認めた。 洞内に充满していた腫瘤塊は非常に柔らかく， 暗赤色ないし部分的に灰白色で浮腫状，多量の 凝血塊を含んでいた。病変は中鼻道を経て左鼻 腔に及んでいたが，周囲に浸潤や癒着を認めず， 比較的容易に剥離摘出できた（図４）。腫瘤塊を 豩離摘出後に洞内を観察すると，左上顎洞の粘 膜は自然孔部を除いてほぼ正常に存在していた。 な敃，篩骨洞も同時に開放したが，肥厚した粘 膜が認められた。術中は多量の出血をみたが， 病変摘出後は容易に止血できた。術中の総出血 量は約 $500 \mathrm{ml}$ であった。

病理組織学的所見: Hematoxylin-Eosin (HE) 染色で, やや浮腫性の多列線毛円柱上皮を伴い, 粘膜直下にびまん性の出血と壞死，へモジデリ ンの著明な沈着を認めた(図 5 )。血管腫や癌腫
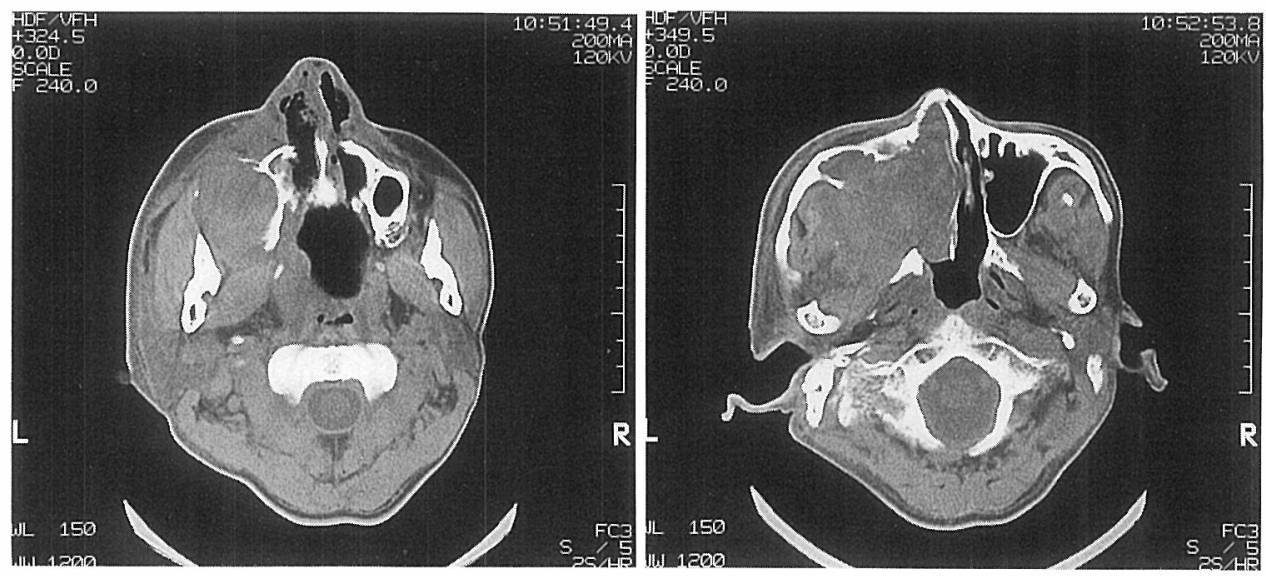

図 3 鼻·副鼻腔 CTscan 検查所見

左上顎洞から左鼻腔に膨張性・進展性に存在する mass を認める。左上顎洞の前壁下部ならびに 内側壁, 外側壁, 翼突起を除く後壁の骨欠損がみられる. 


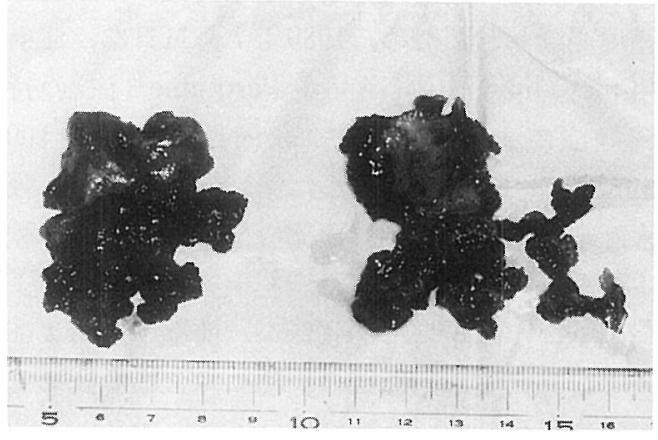

図 4 摘出された腫瘤性病恋

腫瘤の表面は凹凸状を呈し，非常に柔らかい。暗 赤色ないし部分的に灰白色で浮腫状, 凝血塊を含 んでいた，左は鼻腔側より，右は上顎洞開放部よ り摘出された。
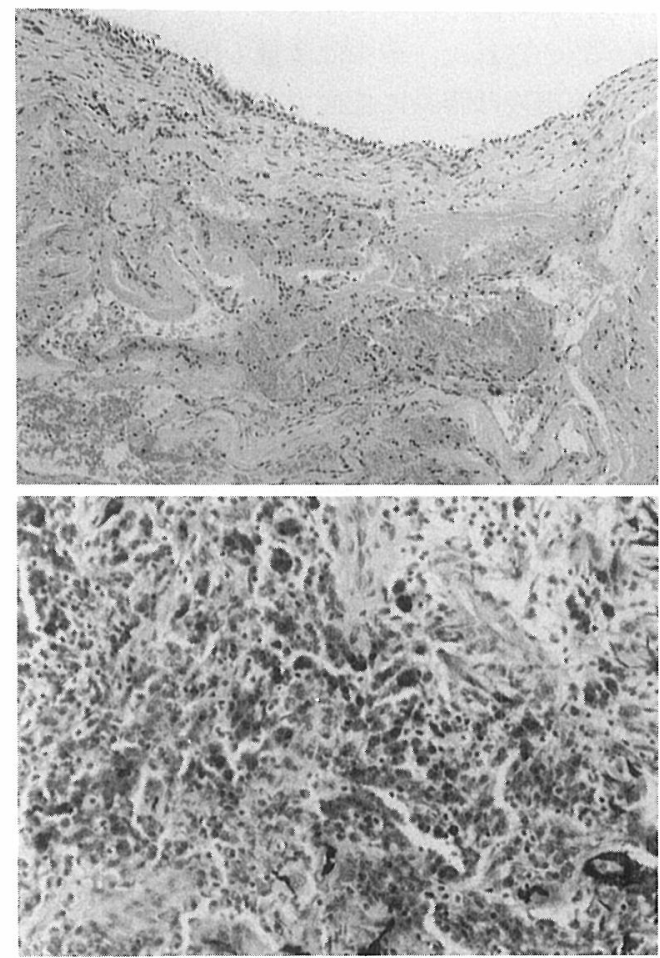

図 5 摘出された病変の病理組織学的所見 (HE 染色)

表層は多列線毛円柱上皮で覆われ, 粘膜下にはび 屯ん性の出血と壊死，へモジデリンの著明な沈着 を認める $($ 上：×40 下：×100)
などの腫瘍の所見はみられず，病理組織学的診 断は出血と壇死を伴う鼻・副鼻腔粘膜といらこ とであった。

経過：臨床的にはいわゆる上顎洞血瘤腫と診 断された。術後経過は良好で，1989年 7 月27日 に退院した. 術後約 1 年 7 力月経過しているが, 再発の徴候はみられていない.

\section{考察}

いわゆる上顎洞血瘤腫は片側の鼻閉塞ならび に鼻出血, 煩部腫脹などの臨床症状に加党て, 画像診断で骨破壊を伴らことがあり，悪性腫瘍 を疑わせるが，洞内に易出血性の腫瘤(血瘤)が 存在し, 病理組織学的には悪性所見はなく, 本 質的には良性疾患と考光られているものである。 本邦では田所1)により報告されたものが最初と されているが，現在でもその本態や成因につい ての明確な結論は出ていない、したがって，本 症は洞内に血瘤，才なわち凝血塊を有し，病理 組織学的に悪性所見のないものに対する臨床的 診断名といら考光方が一般的である2)31.

しかしながら，凝血塊をもたらした原因を病 理組織学的に検索を行らことは重要であり，い わゆる血瘤腫として報告されたもののらち，血 管腫などの病理組織学的な確定診断がなされて いるものもあり4), これらは本来病理学的な診 断名を用いるべきものと思われる。ところが， 病理組織学的に跓腫瘍や炎症性産物として確定 できないもの，すなわち壊死組織と出血巣のみ からなるものもみられる4)5). 本症例も病理組 織学的に血管腫などの腫瘍性病変や炎症性病変 の所見を欠さ，多列線毛円柱上皮に覆われてい るものの，粘膜下は壊死組織と出血が主体であ り，へモジデリンの沈着も認められ，長期間の 出血の反復を示唆させた，以上のことから，臨 床的に凝血塊を認め, 病理組織学的に出血と壊 死組織が主体で腫瘍や炎症などの所見がみられ ないものに限り，いわゆる血瘤腫といら臨床的 診断名を用いるべきものと思われる。

一般に本症は上顎洞自然孔周辺から発生して 上顎洞と鼻腔に向かって亜鈴状に発育し，周囲 
組織との癒着は少ないとされる3). 本症例でも, 癒着はなく, 術後観察で自然孔部を除いて左上 顎洞粘膜が注涪正常に存在していたことから， 同様に自然孔付近より生じて鼻腔ならびに上顎 洞に向かって発育増大したものと考光られる。

その成因は明確ではないが，諸説みられる。 粘液性鼻茸内の出血や生体異常修復過程の悪循 環，血管腫に起因するものなどの他，出血性鼻 茸との異同も論じられている2) 4)6). 本症例の 手術時所見でも術中きわめて出血が多く，低血 圧法を併用したにもかかわらず，総出血量は約 $500 \mathrm{ml}$ であり, 副鼻腔手術としてはかなり大 量であったといえる. しかも, 腫瘤摘出後は容 易に止血できたことから，腫瘤性病変そのもの がきわめて易出血性の性格を有していたものと 考えられる.そして, 病理組織学的にやや浮腫 性の多列線毛円柱上皮に覆われていたことを考 慮すると, 出血性鼻茸と同じ病態もしくは類縁 の疾患を基礎にして生じたといら可能性も考兄 られる. 出血性鼻茸は鼻内に久られる易出血性 の鼻茸の症候学的な総称といらべきものであり， その本態は血管腫(毛細管性血管腫)ならびに血 管拡張性鼻茸 (telangiectatic polyp), 炎症性産 物などが含まれるとされる7)。すなわち, 出血 性鼻茸も臨床的診断名であるといってょく，そ の点についてはいわゆる血瘤腫と類似している といえる。したがって，次に述べるような推測 も考光られる.

すなわち, 出血性鼻茸と同様な病変が上顎洞 自然孔付近に生じて発育すると，自然孔を閉鎖 し，上顎洞が閉鎖腔になり，そこへ出血が頻回 に反復すると内圧の上昇が生じることになる. 内圧の上昇は組織の循環障害を引き起こし，壊 死に陥れる，組織壞死と内圧上昇はさらに血管 の破綻から出血を引き起こし, 内圧はさらに上 昇し，悪循環をきたすことになる，その結果， 術後性に生じる副鼻腔囊胞と同様に病変は膨張 性に増大するとともに，骨破壊をきたすことに なる.このような過程を経て, 病理組織学的所 見が出血性鼻茸と異なるものに変化していくの
ではないかと思われる，以上は推測にすぎない が，本症は出血性鼻茸とともにその病態や成因 を考觉てみる必要もあるのではないかと思われ る.

したがって，基礎になった疾患は血管腫や血 管拡張性鼻茸，炎症性産物などと異なったもの であっても，容易に閉鎖腔に陥りや寸い上顎洞 などの副鼻腔の持つ解剖学的特殊性によって, いわゆる血瘤腫が二次的に形成されたといらこ とが考光られ，同様に本症が二次的産物である と考察されている報告も又られている344.

一方，本症との鑑別疾患としては，その臨床 所見から上顎洞の腫瘍性疾患, 特に悪性腫瘍と の鑑別が問題となることが多(3)899)．その第一 の理由は本症がしばしば骨破壊を認めることで ある、本症例でも画像診断で上下の骨壁を除い て著明な骨破壊が認められた。しかしながら， 本症の場合は比較的緩慢な発育増大ならびに内 圧上昇に起因するものと考兄られ，癌腫のよう に浸潤性に破壊するといらょり，本症例もそう であったように膨張性の骨破壊をきたすことが 多いようである3)。しかし，必ずしもこれが鑑 別の決め手になるといらものではないと考劣ら れる．第二の理由は部分的な組織生検を行って も壊死組織であることが多いことから, 悪性腫 瘍に伴ら壊死組織との区別がつさにくいことで ある. 結局, 本症例でも手術直前まで悪性腫瘍 を疑っていたが，出血は多いものの，腫瘤性病 変は容易に周囲から剝離でき, 注正常な粘膜 が残存していたといら術中・術後の観察所見か ら本症を疑い，最終的には全摘出した組織標本 の病理組織学的所見により診断がなされた。い ずれにしろ，本症例の診断のためには上顎洞試 験開放術を含む副鼻腔手術を施行し，洞内を詳 細に観察するとともに，可及的に病変部を全摘 出して病理組織学的検索を行う必要があるとい 光る。

\section{おわりに}

著明な骨破壞を伴ったいわゆる上顎洞血瘤腫 の一例を経験した，その臨床症状と画像診断か 
らは当初悪性腫瘍が強く疑われたが，術中・術 後所見と病理組織学的所見から本症と診断した. 本症例を報告するとともに，本症の本態と成因 について考察を行った.

\section{参考文献}

1）田所喜久馬：上顎洞血瘤二就テ.大日耳鼻 23 : $359 \sim 360,1917$.

2）鶴田至宏, 宮原 裕, 佐藤武男, 他 : 上顎洞悪 性腫瘍を疑ったいわゆる血瘤腫 2 症例. 耳喉頭 頸 $61: 131 \sim 136,1989$.

3）桐谷伸彦, 青木和博, 足川哲夫, 他 : 悪性腫瘍 が疑われた上顎洞血瘤腫一臨床像並びに成因 に関する考案一. 耳展 $33: 449 \sim 456,1990$.

4）尾崎正義, 酒井俊一, 池田 寛：鼻腔・副鼻腔 血瘤腫25例. 耳喉 $49: 53 \sim 58,1977$.

5）斉藤龍介, 大道卓也, 陶山貴世子, 他：上顎洞 血瘤腫治療に扮ける問題点.耳喉 $58: 327 \sim 334$,
1986.

6）白川吾一郎：鼻腔並二副鼻腔血瘤腫二就テ.大 日耳鼻 $38: 413 \sim 441,1932$.

7）野村恭也：鼻中隔疾患. 臨床耳鼻咽喉科学 3 一鼻科編 (澤木修二, 他 編)．95～112頁，中外 医学社, 東京, 1977.

8）谷本秀司, 古市陽夫, 金森邦彦, 他：悪性腫瘍 を思わせた上顎洞血管腫(いわゆる血瘤腫)の 1 例. 耳喉 $47: 115 \sim 120,1975$.

9）石田春彦, 法貴 昭, 山形健一, 他：鼻 - 副鼻 腔血瘤腫 5 例一上顎癌を疑わせた 1 例を中心 として一.耳鼻臨床 $79:$ 923 929, 1986.

$$
\left(\begin{array}{l}
\text { 原稿受付 : 平成 } 3 \text { 年 } 2 \text { 月 } 19 \text { 日 } \\
\text { 原稿採択 : 平成 } 3 \text { 年 } 3 \text { 月 } 13 \text { 日 } \\
\text { 別刷請求先 : 川井田政弘 } \\
\text { 个170 東京都豊島区南大塚2-8-1 } \\
\text { 東京都立大塚病院耳鼻咽喉科 }
\end{array}\right)
$$

